\title{
Migrant Students Dilemma: Place Attachment as Role Mediator Between Residential Satisfaction, Pro- Environmental Behavior and Intention to Move
}

\author{
Ika Herani ${ }^{1}$, Muhammad Ilman Fadhillah ${ }^{2}$, Fara Rosana Devi ${ }^{3}$ \\ $\left\{\right.$ herani@ub.ac.id $\left.{ }^{1}\right\}$ \\ Psychology, University of Brawijaya, Indonesia ${ }^{1,2,3}$
}

\begin{abstract}
A boarding house or a rent house is an exciting phenomenon study with students as the main character. When individuals feel attached to a place and feel satisfied in theory, they will take care of the area and do not want to move. This research aimed to determine the role of residential satisfaction on pro-environmental behavior and Intention to move for migrant students and know the position of place attachment as the mediator between residential roles satisfaction with pro-environmental behavior Intention to move. This research used a quantitative study, and the sampling technique used accidental sampling, total data of 401 migrant students. The research instrument used was the residential satisfaction scale, place attachment scale, new ecological paradigm (NEP) scale, and Intention to scale. The analysis technique used is multiple regression analysis. The result of this study indicates that residential satisfaction has a positive role in placing attachment. The Place attachment does not have a significant
\end{abstract}

Keywords: Intention to move, migrant students, pro-environmental behavior, place attachment, residential satisfaction

\section{Introduction}

Merantau has become the Indonesian people's living culture; ethnic groups in Indonesia with a culture of migration include the Batak, Bugis, Javanese, Madurese, and Minangkabau tribes [1],[2]. Merantau can define individuals who go from their place of origin to other places to live or seek experiences. Jatmiko [3] explains that wandering can also happen to individuals who will continue their higher education education. He also added that not a few individuals who have graduated from high school choose to continue their higher education outside their home regions. Individual immigrants will experience conditions that are different from their home regions; from these differences, individual migrants, in this case, students, must adjust to their new environment. explains that wandering can also happen to individuals who will continue their higher education education. He also added that not a few individuals who have graduated from high school choose to continue their higher education outside their home regions. Individual immigrants will experience conditions that are different from their home regions; from these differences, individual migrants, in this case, students, must adjust to their new environment [4].

Utomo [5] explained that migrant students would choose a temporary place to live, namely boarding or renting a house. A boarding house or often called a boarding house, is a rented room (booked) for a certain period. Generally, room bookings are made for one year and have a 
function as a temporary residence. Hajar et al [6] found that seven factors influence migrant students choosing boarding houses, including environmental factors, rental prices, facilities, references, location, security, and services. The same thing conveyed by Badri, who found several factors that influenced migrant students in choosing a boarding house, namely the distance from the boarding house, the influence of friends, economic factors, the cleanliness of the boarding house, and a comfortable place.

Some of the factors above sometimes trigger student behavior to move places of residence. Intention to move based on a desire to find a better place and dissatisfaction with the current environment [7]. Research related to satisfaction with a house or home of residence has two types of functions: a tool to predict behavior or Intention to stay or move from the current place and as a criterion for assessing the quality of housing or occupancy [8].

According to Hartono and Gianawati [9], boarding houses have a positive function, namely a place as a temporary home, a place to study, and a place to rest that should be cared for and cared for by its residents. Students' concerns and concerns for the environment has often based on cultural tendencies. They are identical to the "concern-behavior gap," namely psychological factors that hinder student behavior adjustment despite their concern [12]. Students have often been identifying as persons with higher education. Meyer's [10] surveyed 559 undergraduate art students and found that students spend more time on campus, the more knowledge they gain. This will then lead individuals to carry out pro-environmental behaviors such as recycling or saving on paper expenses.

Pro-environmental behavior (PEB) is defining as behavior that impacts environmental sustainability [10]. The opinion of Homburg and Stolberg [11] states that Pro-environmental behavior is a problem solver in the environment. Vicente-molina et al. [13] argue that Proenvironmental behavior can influence attitudes, motivation, and effectiveness. They also explained that some $60 \%$ of research respondents felt that a lack of knowledge limited Proenvironmental behavior. In line with this research, Kocsis explains that knowledge and attitudes are necessary because they can potentially impact behavior formation. Behavior formation can occur when there is an interaction between an individual and their environment [14].

The existence of unique opportunities to participate in an activity together in their environment will increase interest in the background. Each place will provide a particular experience [15]. Place attachment is a feature that connects a business with individuals [16]. According to Scannell and Gifford [17], place attachment occurs due to emotional and cognitive ties to a place.

Kusumowidagdo, Sachari, and Widodo [15] argue that place attachment can occur when individuals occupy a place for an extended period. It can indicate that the individual has satisfaction with the place he lives. Pride in occupying a home or what can be said as residential satisfaction can be defined as individuals who have a quality of life and well-being in their environment [18].

Ytrehus and Pacione [20] argue that residential satisfaction is an individual assessment of their residential environment's quality. Widya et al [8] later strengthened this statement and explained that the evaluation was subjective. Each individual has his or her views based on differences in culture, socio-economy, and expectations. Therefore, the assessment has determined how their residence can meet their needs to achieve the desired things.

Based on statements from Widya et al [8], residential satisfaction can influence positive or negative attitudes and behaviors. Pro-environmental behavior is a positive attitude, and actions can be generated [21]. Widya et al [8] also argue that place attachment can have used as a mediating variable in determining desired behavior, such as pro-environmental behavior. Amerigo and Aragones [7] explain that individuals who are satisfied with the environment in 
which they live will tend to have consistent behavior in caring for their surrounding environment.

Based on the description above, students with higher education should have a more proenvironmental behavior. However, this cannot always happen because of other factors, one of which is cultural differences. Overseas students often have cultural values that are different from the local culture, and cultural differences can be factors that hinder individuals from caring about the environment they live in now. In this case, culture is not the single factor that can influence pro-environmental behavior. There is satisfaction with overseas students' residence, which can play a role in overseas students' attachment to the place they live. This attachment then allows the formation of behavior related to the environment, which is pro-environmental behavior.

Similar research has been conducting but only measures three variables without measuring pro-environment, and the research subjects are residents who live in certain areas. In the current study, adding one variable, namely pro-environment and changing the subject into a student, follows the field's recent phenomena. Where students today are one of the agents of change for the environment in the future.

Thus, the researcher is interested in proving the role of residential satisfaction, Intention to move towards pro-environmental behavior among overseas students who live in boarding houses by making place attachment as the mediator of the two variables. This research expects to consider the parties concerned, in this case, the boarding house manager or the surrounding community, to pay more attention to overseas students the satisfaction and attachments to generate pro-environmental behavior.

The hypotheses presented in this study are:

$\mathrm{H} 1$ : there is a role of residential satisfaction on place attachment

$\mathrm{H} 2$ : there is a role of place attachment to pro-environmental behavior

$\mathrm{H} 3$ : there is a role of residential satisfaction towards pro-environmental behavior

$\mathrm{H} 4$ : there is a role of place attachment to Intention to move

\section{Method}

This research is a quantitative study using correlational research methods. The population in this study was students in Indonesia. This study uses a sample that is a small part of some predetermined characteristics in the population. The number of respondents was determined with the help of software $\mathrm{G} *$ power 3.5.1, and obtained $\mathrm{N}=107$; however, the researcher did not limit the number of respondents that the software had determined, this has done so that the researcher received broader data and anticipated the possibility of invalid data.

This study uses an accidental sampling technique where the researcher accidentally finds an individual and has criteria that match the research respondents.

The criteria for the subjects in this study are:

- Active students

- Overseas students

- $\quad$ Living in a boarding house or contract house

The research instrument has been used for measurement to produce accurate quantitative data with a scale. There are four instruments used; the researcher adapts and tests the tools used. 


\subsection{Residential satisfaction instruments}

Researchers used an adaptation of the residential satisfaction scale prepared by Widya, Kusuma, and Lubis (2019), totaling 74 items divided into two aspects, namely physical and nonphysical elements. The number for each component, namely the physical component of 48 things and the non-physical part of the 26 items. The statements on items are arranged on a Liker scale of 1-5 for 1 "very dissatisfied" and 5 for "very satisfied."

\subsection{Place attachment instrument}

Researchers used an adaptation of the place attachment scale compiled by Harmon, Zinn, and Gleason [16], totaling 21 items divided into three dimensions: place dependence, place identity, and place-based affective. The articles on things are arranged on a Likert scale of 1-5 for 1 "very unsuitable" and 5 for "very suitable."

\subsection{Pro-environmental behavior instruments}

Researchers used the adaptation results of the Felia scale (2018), which is the NEP scale based on Dunlap's [22] theory, which consists of 15 items which have divided into five dimensions, namely limit to growth, anti-anthropocentrism, the balance of nature, antiexemptionalism, and eco-crisis. Statements on items are arranged on a Liker scale 1-5 for 1 "strongly disagree" and 5 for "strongly agree."

\subsection{Intention to move the instrument}

Researchers used the theoretical concept presented by Morris et al. [23]. Two dimensions exist in this theory, namely mismatch, where this is a reaction when individuals cannot meet their needs in the current environment. The second dimension is the opportunities elsewhere, where this is a reaction when there is a conflict that cannot be resolved and leads to finding a new place to live. This scale was adapted by Widya et al. 2019, with a reliability of 0.90 .

The data collection process is carried out online by creating a Google form and disseminating it through various social media to access Indonesian students. Four hundred fifteen data have been obtaining from the scale distribution process, but 401 scales have proceeded further.

\section{Result and Discussion}

Multiple regression is used to test whether there is a role in each of the measured variables. From the respondent's data results, as many as 401 students came from several regions spread throughout Indonesia and represented all provinces. This type of education belongs to the university and Polytechnic levels.

Table 1. Description of research subjects

\begin{tabular}{clrrr}
\hline Type of Data & \multicolumn{1}{c}{ Category } & Amount & Percentage & Total \\
\hline \multirow{2}{*}{ Gender } & Female & 108 & 26.93 & $100 \%$ \\
\cline { 2 - 4 } & Male & 293 & 73.07 & \\
\hline
\end{tabular}




\begin{tabular}{|c|c|c|c|c|}
\hline \multirow[t]{4}{*}{ Age } & $17-20$ & 183 & 45.64 & \multirow{4}{*}{$100 \%$} \\
\hline & $21-30$ & 213 & 53.12 & \\
\hline & $31-40$ & 3 & 0.75 & \\
\hline & $41-50$ & 2 & 0.50 & \\
\hline \multirow{3}{*}{$\begin{array}{c}\text { Education } \\
\text { Background }\end{array}$} & Vocational & 33 & 7.24 & \multirow[t]{3}{*}{$100 \%$} \\
\hline & Undergraduate & 354 & 88.28 & \\
\hline & Post Graduate & 14 & 3.49 & \\
\hline \multirow[t]{2}{*}{ Residences } & Boarding house & 333 & 83.04 & \multirow[t]{2}{*}{$100 \%$} \\
\hline & $\begin{array}{l}\text { Rentend house / } \\
\text { Apartement }\end{array}$ & 68 & 16.96 & \\
\hline
\end{tabular}

From Table 1, it is found that the research subjects were male as much as $73.97 \%$ and female subjects as much as $26.93 \%$. Most of them were in the age range of 21-30 years, as much as $53.12 \%$. Most of the respondents came from the $\mathrm{S} 1$ education level, as much as $88.28 \%$. The type of residence is a room for rent or boarding house at $83.04 \%$.

Most of the research subjects came from Brawijaya University, and the rest came from other educational institutions in Indonesia.

\subsection{Results}

Table 2. The results of hypothesis testing

\begin{tabular}{|c|c|c|c|c|c|}
\hline \multicolumn{2}{|c|}{ Variable } & Coefficient & $\mathbf{p}$ & Explanation & Conclusion \\
\hline \multirow{4}{*}{$\begin{array}{l}\text { Residential } \\
\text { Satisfaction - } \\
\text { Place } \\
\text { Attachment - } \\
\text { Pro } \\
\text { Environment } \\
\text { al behavior }\end{array}$} & $\begin{array}{l}\text { Line a } \\
\text { (RS-PA) }\end{array}$ & 0.217 & 0.000 & $\begin{array}{l}\text { Significant and } \\
\text { play a positive role }\end{array}$ & \multirow{4}{*}{$\begin{array}{l}\text { There is no role } \\
\text { for Place } \\
\text { Attachment as a } \\
\text { mediator }\end{array}$} \\
\hline & $\begin{array}{l}\text { Line b } \\
\text { (PA-PEB) }\end{array}$ & 0.212 & 0.454 & $\begin{array}{l}\text { Insignificant and } \\
\text { plays a positive } \\
\text { role }\end{array}$ & \\
\hline & $\begin{array}{l}\text { Line c } \\
\text { (RS-PEB) }\end{array}$ & -0.001 & 0.838 & $\begin{array}{l}\text { Insignificant and } \\
\text { plays a negative } \\
\text { role }\end{array}$ & \\
\hline & $\begin{array}{l}\text { Line c' } \\
\text { (RS-PA-PEB) }\end{array}$ & -0.006 & 0.561 & $\begin{array}{l}\text { Insignificant and } \\
\text { plays a negative } \\
\text { role }\end{array}$ & \\
\hline \multirow{4}{*}{$\begin{array}{l}\text { Residential } \\
\text { Satisfaction - } \\
\text { Residential } \\
\text { Satisfaction - } \\
\text { intention to } \\
\text { move }\end{array}$} & $\begin{array}{l}\text { Line a } \\
\text { (RS-PA) }\end{array}$ & 0.217 & 0.000 & $\begin{array}{l}\text { Significant and } \\
\text { play a positive role }\end{array}$ & \multirow{4}{*}{$\begin{array}{l}\text { There is a role of } \\
\text { Place Attachment } \\
\text { as a mediator (full } \\
\text { meditation) }\end{array}$} \\
\hline & $\begin{array}{l}\text { Line b } \\
\text { (PA-ITM) }\end{array}$ & -0.111 & 0.000 & $\begin{array}{l}\text { Significant and } \\
\text { play a negative role }\end{array}$ & \\
\hline & $\begin{array}{l}\text { Line } \\
\text { (RS-ITM) }\end{array}$ & -0.033 & 0.000 & $\begin{array}{l}\text { Significant and } \\
\text { play a negative role }\end{array}$ & \\
\hline & $\begin{array}{l}\text { Line c' } \\
\text { (RS-PA-ITM) }\end{array}$ & -0.009 & 0.159 & $\begin{array}{l}\text { Significant and } \\
\text { play a negative role }\end{array}$ & \\
\hline
\end{tabular}

From Table 2, the relationship between residential satisfaction and place attachment as a mediator does not have a significant role. Meanwhile, there is a considerable role in variable residential satisfaction with the place attachment as a mediator on the Intention to move.

\subsection{Discussion}


Based on the results of hypothesis testing, residential satisfaction has a positive role in place attachment. The analysis result means that residential satisfaction has a part of $30.1 \%$ on place attachments. These results followed by research description results, which show that $51.3 \%$ or as many as 206 respondents are in the high category on the residential satisfaction variable. As much as $70.3 \%$ or 282 respondents are in the high sort on the place attachment variable.

Tabernero, Briones, and Cuadrado [24] supported this result, who found a positive relationship between residential satisfaction and place attachment. The results are in line with the definition and application of place attachments in overseas students. Place attachment is a dimension that connects residence with overseas students [16]. Place attachments may occur if overseas students occupy a place for a long time [15]. This allows an indication that the overseas students are satisfied with the place they are living. In the research of Tabernero, Briones, and Cuadrado [24] it was also found that the length of time a student stays has a positive effect on place attachment. The positive impact happens because place attachments are dynamic, so they develop from time to time. At the same time, residential satisfaction is more static because it is more determined by the residence's physical characteristics.

Hypothesis test results also show that place attachment does not have a significant effect on Pro-environmental behavior. Place attachment only has a $0.15 \%$ role in Pro-environmental behavior. This supported the research description results, which show $74.5 \%$ or as many as 299 respondents to the Pro-environmental behavior variable are in the medium category. In comparison, the place attachment variable is $70.3 \%$, or 282 respondents are in the high sort. The results of this hypothesis testing are contrary to the theoretical basis and the effects of previous studies.

Several factors can cause the absence of a significant role between place attachment and pro-environmental behavior. One aspect is researchers' modification on the pro-environmental behavior variable scale (new ecological paradigm scale). Researchers made modifications because the new environmental paradigm scale used in a broad ecological context and items from measuring instruments tend to lead to a pro-environmental attitude [6].

The results of further hypothesis testing found that residential satisfaction does not significantly affect pro-environmental behavior. Residential satisfaction only has a role of $0.01 \%$ with pro-environmental action. The results of this hypothesis test also show that residential satisfaction has a negative role in pro-environmental behavior. This result means that the higher the residential student satisfaction, the lower the pro-environmental action. This result contradicts Amerigo and Aragones [7] statement, which states that if an individual has satisfaction with his / her place of residence, the individual will tend to care for the surrounding environment consistently.

Ajzen [25] stated in Theory of Planned Behavior (TPB) that several variables form a behavior intention which in this study are pro-environmental behavior, including (a) attitudes towards behavior, (b) subjective norms, and (c) behavior control. Like this statement, Duerden and Witt [14] say that knowledge and attitudes toward behavior can influence behavioral intentions. If you reflect on the research hypothesis test results, the positive role that the residential satisfaction variable has on place attachment does not affect pro-environmental behavior among overseas students.

This can happen due to several factors. The first factor, respondents in the study, do not have the right attitude towards the environment where they live overseas. Second, respondents lack knowledge in protecting the environment they live in overseas. Third, respondents have different norms from their place of origin to their place of residence overseas. Fourth, respondents are less able to control their behavior towards the place where they live overseas. Fifth, because the place where they live is temporary, it is possible for respondents not to have 
a sense of belonging to their place of residence not to have the Intention to carry out proenvironmental behavior. Scannell and Gifford [17] stated research, which found that physical and emotional connections to the place of residence have a relationship with action that protects the place where they live, which in this case is pro-environmental behavior. This study also found that the attachment that residents have to their place of residence is natural, not because of culture or population problems with their place of residence.

It is different from the results of hypothesis testing involving the Intention To Move variable. It found that the place attachment has a significant role or $16.3 \%$ of the Intention To Move variable. However, the part that place attachments have for overseas students towards Intention To Move is negative. Like this, residential satisfaction also has a significant role or $7.4 \%$ of the Intention To Move variable but negatively. This indicates that if overseas students have a high Intention To Move, it will decrease due to residential satisfaction and place attachments overseas students own when viewed from research description results, show that $54.8 \%$ or as many as 220 respondents are in the Intention To Move variable's medium category.

Pacione [20] explains that the attitude of living in one place or moving to another place is a decision that occurs when residents have or do not have a living environment that matches their expectations. The results of hypothesis testing in this study are similar to the effects of previous studies conducted by Zenker and Rütter [26], showing that occupancy satisfaction significantly affects occupants' attachment and directly reduces their Intention to move. In research conducted by Morris et al. [23], high occupancy satisfaction results tend to make changes or additions to their occupancy and reduce their Intention to move.

Limitations in this study include collecting data only through online distribution so that researchers cannot help respondents understand the research instruments' contents. The researcher did not translate the measuring device through the sound stages, and the researcher did not carry out a back-translation in translating the research measuring instrument. There is a limitation in the pro-environmental behavior measuring device (NEP scale) where 8 of the 15 items have failed; elimination of these items is due to their lack of reliability. Researchers modified the new environmental paradigm scale, which resulted in the composition of favorable and unfavorable items changing from the previous design. The New Ecological Paradigm scale is widely used in a broad ecological context. It tends to lead to pro-environmental attitudes rather than pro-environmental behavior, while in this study, it is in the context of the living environment. This study has limitations that tend to exist in the measuring instruments used. Interpretation of the research results must have carried out cautiously if subsequent studies also modify similar measuring instruments.

\section{Conclusion}

Residential satisfaction has a positive role in place attachments. Place attachment does not have a significant effect on pro-environmental behavior among overseas students. Residential satisfaction does not have a considerable role in pro-environmental behavior. The Intention to move variable found that place attachment has a significant role in the Intention to move variable even though it is negative. Likewise, residential satisfaction also has adversely affected the part of the variable Intention to move. 


\section{Acknowledgment}

This research conducted with internal grants, and the researchers would like to thank the team and all research respondents who participated in this research.

\section{References}

[1] S. Marta, "Konstruksi Makna Budaya Merantau di Kalangan Mahasiswa Perantau,” J. Kaji. Komun., vol. 2, no. 1, p. 27, 2014, doi: 10.24198/jkk.v2i1.6048.

[2] M. I. Sholik, F. Rosyid, K. Mufa'idah, T. Agustina, and U. R. Ashari, "Merantau Sebagai Budaya (Eksplorasi Sistem Sosial Masyarakat Pulau Bawean),” Cakrawala, vol. 10, no. 2, pp. 143-153, 2016, [Online]. Available: http://www.cakrawalajournal.org/index.php/cakrawala/article/view/39/37.

[3] A. Jatmiko, "Sense Of Place Dan Social Anxiety bagi Mahasiswa Baru Pendatang," KONSELI J. Bimbing. dan Konseling, vol. 3, no. 2, pp. 155-160, 2016.

[4] N. Karmiana, "Hubungan Antara Kecerdasan Emosi dengan Penyesuaian Diri Mahasiswa Perantau Asal Lampung," Skripsi, 2016.

[5] P. Utomo, "Dinamika Pelajar Dan Mahasiswa Di Sekitar Kampus Yogyakarta ( Telaah Pengelolaan Rumah Kontrak Dan Rumah Sewa ),” Univ. Negeri Yogyakarta, no. April, pp. 11-14, 2009.

[6] J. Matematika, K. Mahasiswa, A. Faktor, and D. Indonesia, "Faktor-Faktor Yang Memengaruhi Keputusan Mahasiswa Dalam Memilih Rumah Kost," E-Jurnal Mat., vol. 1, no. 1, pp. 25-31, 2012, doi: 10.24843/MTK.2012.v01.i01.p005.

[7] M. Amerigo and J. I. Aragones, "A theoretical and methodological approach to the study of residential satisfaction," J. Environ. Psychol., vol. 17, no. 1, pp. 47-57, 1997, DOI: 10.1006/jevp.1996.0038.

[8] A. T. Widya, H. E. Kusuma, and R. A. Lubis, "The correlational relationship between residential satisfaction, place attachment, and intention to move: A preliminary study in Belawan, Medan," J. Reg. City Plan., vol. 30, no. 3, pp. 191-210, 2019, DOI: 10.5614/jpwk.2019.30.3.2.

[9] Rizki Dwi Hartono dan Nur Dyah Gianawati, "Faktor-Faktor Yang Menyebabkan Remaja Berperilaku Menyimpang ( The Factors That Causes Teenagers Behave Deviant)," Sos. Dan Polit., no. Tingkahlaku Menyimpang, 2013, [Online]. Available: http://repository.unej.ac.id/bitstream/handle/123456789/58735/Rizki Dwi Hartono.pdf?sequence=1.

[10] A. Meyer, "Heterogeneity in the preferences and pro-environmental behavior of college students: The effects of years on campus, demographics, and external factors," J. Clean. Prod., vol. 112, pp. 3451-3463, 2016, DOI: 10.1016/j.jclepro.2015.10.133.

[11] A. Homburg and A. Stolberg, "Explaining pro-environmental behavior with a cognitive theory of stress," J. Environ. Psychol., vol. 26, no. 1, pp. 1-14, 2006, DOI: 10.1016/j.jenvp.2006.03.003.

[12] E. Tezel, M. Ugural, and H. Giritli, "Pro-environmental Behavior of University Students: Influence of Cultural Differences," Eur. J. Sustain. Dev., vol. 7, no. 4, pp. 43-52, 2018, DOI: 10.14207/ed.2018.v7n4p43.

[13] M. A. Vicente-Molina, A. Fernández-Sáinz, and J. Izagirre-Olaizola, "Environmental knowledge and other variables affecting pro-environmental behavior: Comparison of university students from emerging and advanced countries," J. Clean. Prod., vol. 61, pp. 130-138, 2013, DOI: 10.1016/j.jclepro.2013.05.015.

[14] M. D. Duerden and P. A. Witt, "The impact of direct and indirect experiences on the development of environmental knowledge, attitudes, and behavior," J. Environ. Psychol., vol. 30, no. 4, pp. 379-392, 2010, doi: 10.1016/j.jenvp.2010.03.007.

[15] A. Kusumowidagdo, A. Sachari, and P. Widodo, "Visitors' Perception towards Public Space in Shopping Center in the Creation Sense of Place," Procedia - Soc. Behav. Sci., vol. 184, no. August 2014, pp. 266-272, 2015, doi: 10.1016/j.sbspro.2015.05.090. 
[16] L. K. Harmon, H. C. Zinn, and M. Gleason, "Place Identity, Place Dependence, and Place-Based Affect : Examining Their Relationship to Participation in Educational and Interpretive Programs at Isle Royale National Park," People, Places, Park. Proc. 2005 Georg. Wright Soc. Conf. Park. Prot. Areas, Cult. Sites., pp. 149-156, 2006.

[17] L. Scannell and R. Gifford, "Defining place attachment: A tripartite organizing framework," J. Environ. Psychol., vol. 30, no. 1, pp. 1-10, 2010, doi: 10.1016/j.jenvp.2009.09.006.

[18] D. Zhan, M. P. Kwan, W. Zhang, J. Fan, J. Yu, and Y. Dang, "Assessment and determinants of satisfaction with urban livability in China," Cities, vol. 79, no. February, pp. 92-101, 2018, doi: 10.1016/j.cities.2018.02.025.

[19] S. Ytrehus, "Interpretation of housing needs - A critical discussion," Housing, Theory Soc., vol. 17, no. 4, pp. 166-174, 2000, doi: 10.1080/140360900300108591.

[20] M. Pacione, "Urban liveability: A review," Urban Geogr., vol. 11, no. 1, pp. 1-30, 1990, doi: 10.2747/0272-3638.11.1.1.

[21] H. Ramkissoon, L. D. Graham Smith, and B. Weiler, "Testing the dimensionality of place attachment and its relationships with place satisfaction and pro-environmental behaviours: A structural equation modelling approach," Tour. Manag., vol. 36, no. June, pp. 552-566, 2013, doi: 10.1016/j.tourman.2012.09.003.

[22] R. E. Dunlap, K. D. Van Liere, A. G. Mertig, and R. E. Jones, "Measuring endorsement of the new ecological paradigm: A revised NEP scale," J. Soc. Issues, vol. 56, no. 3, pp. 425-442, 2000, doi: 10.1111/0022-4537.00176.

[23] mary Morris, Earl W \& winter, "Housing Adjustment. Satisfaction. and Quality/Quantity Considerations in Housing: the Case of Oaxaca De Juarez," Proc. Annu. Conf. Environ. Des. Res. Assoc., no. December, p. 7, 1988.

[24] C. Tabernero, E. Briones, and E. Cuadrado, "Cambios en la satisfacción residencial y el apego al lugar en función del tiempo de residencia," Psyecology, vol. 1, no. 3, pp. 403-412, 2010, doi: $10.1174 / 217119710792774771$.

[25] A. Icek, "The Theory of Planned Behavior Organizational Behavior and Human Decision Processes," Organ. Behav. Hum. Decis. Process., vol. 50, no. 2, pp. 179-211, 1991.

[26] S. Zenker and N. Rütter, "Is satisfaction the key $\alpha$ The role of citizen satisfaction, place attachment and place brand attitude on positive citizenship behavior," Cities, vol. 38, pp. 11-17, Jun. 2014, doi: 10.1016/j.cities.2013.12.009. 